ppi $201502 Z U 4645$

Esta publicación cientifica en formato digital es continuidad de la revista impresa ISSN-Versión Impresa 0798-1406 / ISSN-Versión on line 2542-3185Depósito legal pp

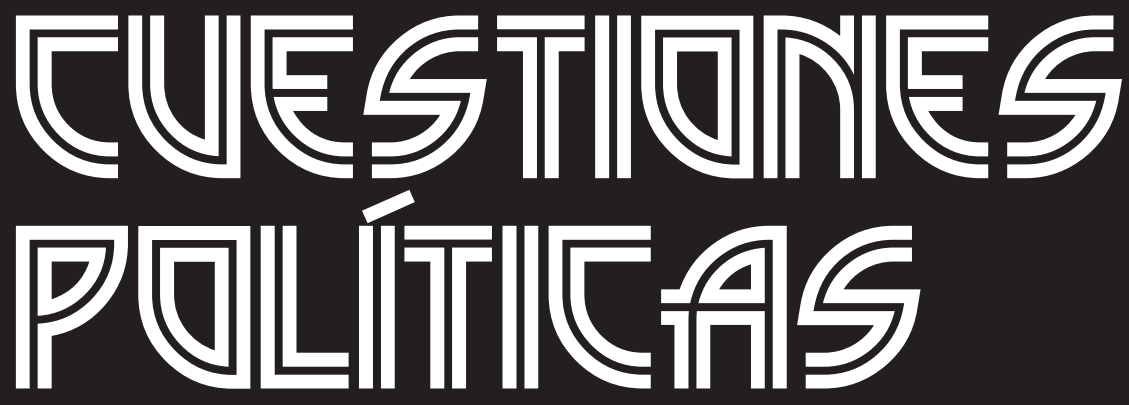

Instituto de Estudios Políticos y Derecho Público "Dr. Humberto J. La Roche' de la Facultad de Ciencias Jurídicas y Políticas de la Universidad del Zulia Maracaibo, Venezuela
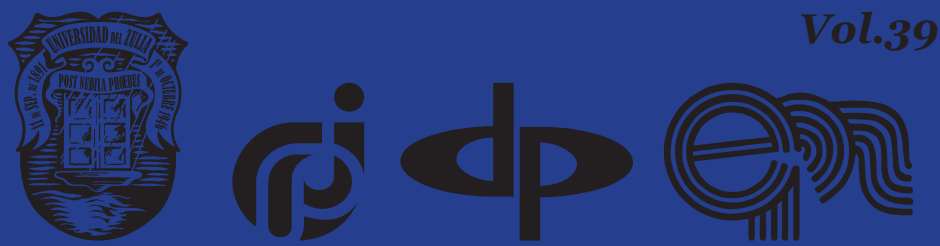


\title{
To the issue of identifying some objects of operational protection by criminal police units of the National Police of Ukraine
}

\author{
DOI: https://doi.org/10.46398/cuestpol.3968.44
}

\author{
Chyzh Sergii Anatoliyovich * \\ Shahova Kateryna Volodymyrivna ** \\ Dereviahin Oleksii Oleksandrovich *** \\ Dal Adam Lavrentiiovych ***** \\ Saltovets Sergii Anatoliyovich *****
}

\section{Abstract}

The subject of the investigation are the operational maintenance objects of the machine-building complex and the recreational-tourism sphere by criminal police divisions. The research methodology includes the following methods: general and special legal: monographic method, method of analysis and synthesis, comparative legal method, classification method, statistical method, abstractlogical method. Scientific approaches to operating service definition are considered. An analysis of the machinery construction complex and the tourist and recreational field was carried out to achieve high standards of its operational service. As a practical dignified facility of the machinery construction complex and the tourist and recreational sphere were ordered in appropriate groups to identify those in need of operational maintenance. It is concluded that the regulations of the Ministry of the Interior and the National Police of Ukraine do not contain provisions that clearly define the content of the institution of operational services and its place in the system of operational and investigative units to combat crime.

* $\quad$ Ph.D in Law, Senior Lecturer of the Department of Pre-investigative and Detective activity of Kharkiv National University of Internal Affairs. ORCID ID: https://orcid.org/oooo-0003-4296-3246. Email: S.chij82@Gmail.com

** Ph.D in Law, Doctoral Student of Kharkiv National University of Internal Affairs. ORCID ID: https:// orcid.org/oooo-0002-6431-3757. Email: katerina.kharkov@ukr.net

*** Ph.D in Law, Assistant professor of the Department of Preinvestigative and Detective activity of Kharkiv National University of Internal Affairs. ORCID ID: https://orcid.org/oooo-0003-1622-5549. Email: yasnoesolnishko@ukr.net

${ }^{* * * *}$ Ph.D in Law, Assistant professor of the Department of Preinvestigative and Detective activity of Kharkiv National University of Internal Affairs. ORCID ID: https://orcid.org/oooo-0002-2775-2523. Email: adam.dahl13@gmail.com

**** Ph.D in Law, Senior Lecturer of the Department of Preinvestigative and Detective activity of Kharkiv National University of Internal Affairs. ORCID ID: https://orcid.org/oooo-0oo1-6864-9349. Email: Ax4343ax@gmail.com 
Keywords: operational facilities; Ukraine's opposition; machinery construction complex; spa-recreational; criminal law.

\section{Respecto a la identificación de algunas instalaciones operativas por unidades de la policía criminal}

\section{Resumen}

El tema de la investigación son los objetos de mantenimiento operativo del complejo de construcción de máquinas y la esfera recreativa-turística por parte de las divisiones de la policía criminal. La metodología de investigación incluye los siguientes métodos: legales generales y especiales: método monográfico, método de análisis y síntesis, método jurídico comparado, método de clasificación, método estadístico, método abstracto-lógico. Se consideran enfoques científicos para la definición de servicio operativo. Se efectuó un análisis del complejo de construcción de maquinaria y el ámbito turístico y recreativo para lograr altos estándares de su servicio operativo. Como significado práctico las instalaciones del complejo de construcción de maquinaria y la esfera turística y recreativa se ordenaron en grupos adecuados para identificar a quienes necesitan mantenimiento operativo. Se concluye que el reglamento del Ministerio del Interior y de la Policía Nacional de Ucrania no contiene disposiciones que definan claramente el contenido de la institución de los servicios operativos y su lugar en el sistema de unidades operativas e investigadoras para combatir la delincuencia.

Palabras clave: instalaciones operativas; policía nacional de Ucrania; complejo de construcción de maquinaria; balneariorecreativo; derecho penal.

\section{Introduction}

The strategic investigation units of the National Police of Ukraine set themselves the goal of achieving two interrelated goals in the process of operational protection of economic sector:

a) organization of systematic monitoring of objects and industries in respect of which there are reasonable suspicions about the possibility of illegal actions.

b) establishing strong operational positions on the territory under the jurisdiction of the separate strategic investigation unit of the National Police of Ukraine. 
Chyzh Sergịi Anatoliyovich, Shahova Kateryna Volodymyrivna, Dereviahin Oleksii Oleksandrovich, Dal Adam Lavrentiiovych y Saltovets Sergii Anatoliyovich

698

To the issue of identifying some objects of operational protection by criminal police units of the National Police of Ukraine

Our analysis of scientific research on the problems of operational service of certain sectors of the economy showed that today the problems of operational protection of priority sectors of the economy by criminal police units are not sufficiently studied; scientifically sound proposals for such services are provided only in certain areas of activity of criminal police units, namely:

a) operational protection of agricultural processing enterprises.

b) detection of criminal offenses related to the manufacture, import and distribution of dangerous food products.

c) investigative counteraction to obtaining illegal benefit in the agroindustrial complex.

d) detection and prevention of activities of organized groups in the area of housing and communal services.

e) investigative counteraction to criminal offenses in the sphere of household waste circulation.

f) investigative counteraction to criminal offenses in the sphere of economy committed at the railway transport enterprises.

g) investigative counteraction to criminal offenses in the sphere of economy, which are committed in the course of highways construction.

h) investigative counteraction to criminal offenses related to trafficking in scrap metal.

At the same time, the issues of operational protection of the machinebuilding complex and the resort-recreational sphere by the units of the criminal police remain unexplored.

Based on the above stated, today there is a need to identify the objects of operational protection of the machine-building complex and the resortrecreational sphere by the criminal police units.

\section{Methodology}

In order to achieve the goal of the Article, the following general and special methods of scientific knowledge were used.

Monographic method helped in the study of scientific works of scholars, who examined the problem of operational protection of economic objects.

The methods of analysis and synthesis made it possible to analyze the views of different scientists on the problem under consideration. 
Comparative and legal method allowed to compare various approaches of the scholars to the concept of operational protection of economic objects by criminal police units.

The method of classification was applied for the assignment of the branches of the machine-building complex, as well as the objects of the latter to the relevant groups in order to achieve high standards of their operational protection. The same method was used for identifying the entities of the resort-recreational sphere.

Statistical method was useful when considering the most significant data related to the machine-building complex and resort-recreational sphere in Ukraine.

Abstract and logical method was used to formulate the relevant conclusions and suggestions.

\section{Literature Review}

Since operational and search activities are specific, carried out mainly by covert means and methods, the activities of operational units should be referred to as operational protection, which is a kind of branch of social services that performs specific tasks to ensure legality and rule of law in the fight against crime. After all, the effective organization of operational services of the territory (facilities, industries, economic entities, etc.) contributes to the successful implementation of the principle of social justice in a specific area of legal relations, as it allows to ensure maximum timeliness, completeness and objectivity of the investigation; the inevitability of punishment; the fullest possible compensation for the damage caused to the State and citizens; investigation of crimes and bringing to justice those who committed them.

Some authors understand the term operational protection as the organization of covert work in a designated area, facilities and in the places where stolen items are sold. This preliminary conclusion can be reached by analyzing the position of Professor Lekar (1981), who claims that the operational protection of the sectors and objects of the economy should be understood as a system of operational and investigative and other measures carried out where disguised crimes towards the State assets are committed or may be committed, for the purpose of their timely detection, prevention or disclosure, identification of all persons involved in such crimes, and ensuring the possibility of bringing them to justice. Operational services are based on the untransparent awareness of criminal police units; therefore the latter should focus on the selection, placement and effective use of undercover agents in combination with other forces, means and methods of operational and search activities on previously identified and studied economic entities. 
Chyzh Sergịi Anatoliyovich, Shạhova Kateryna Volodymyrivna, Dereviahin Oleksii Oleksandrovich, Dal Adam Lavrentiiovych y Saltovets Sergii Anatoliyovich

Atmazhytov and Illichov (1986) hold the same opinion on the definition of operational protection. According to them it is the set of measures for the optimal distribution of forces and means that ensure both the receipt of operational and investigative information in the designated areas, at individual objects, among various categories of persons of operational interest, and its timely use to effectively combat crime.

However, according to Berlach (2002), is not only methodically impractical, but also unprofessional to limit the flow of information to unofficial sources. The scholar proves that economic crime due to its latency and material nature of leaving traces in accounting documents can be stopped only in case of a comprehensive flow of information.

We believe that operational service cannot be of high quality if it is based only on information coming from undercover agents. After all, information that covers the situation at the economic object cannot be comprehensive without the use of other sources and opportunities, as each undercover agent acts autonomously, so his (her) intelligence capabilities are limited. At the same time, one should not forget that an undercover agent is somewhat limited in his (her) actions; the importance and volume of information he (she) can get depends on his (her) physiological characteristics, professionalism, position, social status, etc. In addition, all information received from each undercover employee requires careful analysis, systematization and verification. Only in this case, and only to a certain extent, can we talk about an objective assessment of the processes taking place in a particular economic object.

In the light of the foregoing, we should agree with the definition provided by Ilnytskyi (2009), who believes that operational protection is a system of constantly carried out organizational, tactical and operational and search measures aimed at obtaining (from open and secret sources) objective, reliable, real information about the state of operation of the object, which is used to prevent criminal activity, detection and investigation of crimes.

Note that operational protection is not a common concept, which can be given a complete, logically correct definition.

\section{Results and Discussion}

The machine-building complex is a basic branch of the economy, its system-forming element that determines the state of production potential and defense capabilities of the country. The functioning of all other industries largely depends on the results of its activities (Kravchenko and Uvarovskyi, 2017). The machine-building complex of Ukraine includes more than 20 branches, 58 sub-branches, in which 11,267 enterprises work (146 large, 1,834 medium, 9,287 small enterprises), which employ about 1.5 million workers (Amosh, 2017). 
The machine-building complex of Ukraine covers more than 20 specialized branches, i.e. practically all branches of mechanical engineering. Depending on which market the products of the machine-building complex are focused on, they can be conditionally grouped into five groups:

1. Investment (heavy) engineering - a group of industries, the development of which is determined primarily by the investment activity of metallurgical, construction, energy, and transport complexes.

2. Tractor and agricultural machinery - a group of industries whose development depends on the capacity to pay of agricultural producers and processors of agricultural products, as well as partly on public demand.

3. Railway engineering is aimed at meeting the demand of the railway industry of the country.

4. Automotive industry the production of which is focused on the demand of final consumers (production of cars), as well as the needs of enterprises, firms and executive authorities (production of trucks and buses).

5. Electrical engineering, instrument making, machine building is the group of science-intensive industries, so-called components developing in line with the needs of all other industries, including mechanical engineering (Pihul and Pihul, 2018).

The study shows that the most important results in the process of combating crimes in the machine-building complex can be achieved by organizing high-quality operational protection of machine-building complex objects, which can be divided into:

- heavy engineering enterprises.

- agricultural (tractor) engineering enterprises.

- railway engineering enterprises.

- enterprises of the automobile industry.

- enterprises for the manufacture of electrical engineering, instrument-making, and machine tools.

Besides, employees of strategic investigation units of the National Police of Ukraine should take into account the location of machine-building complex facilities, focus on those sectors of the economy that are most represented in certain regions when planning activities for the operational protection of machine-building enterprises. Thus, today the main centers of mechanical engineering are located in the following cities of Ukraine:

Heavy engineering - Kharkiv, Dnipro, Kryvyi Rih, Mariupol, Kyiv, Lviv, Drohobych; 
Chyzh Sergịi Anatoliyovich, Shạhova Kateryna Volodymyrivna, Dereviahin Oleksii Oleksandrovich, Dal Adam Lavrentiiovych y Saltovets Sergii Anatoliyovich

To the issue of identifying some objects of operational protection by criminal police units of the National Police of Ukraine

Electrical industry - Zaporizhzhia, Kharkiv, Odessa, Kiev, Khmelnytskyi, Berdyansk, Poltava, Kamianets-Podilskyi;

Transport engineering - Kharkiv, Dnipro, Kremenchuk, Mariupol, Mykolayiv, Kherson, Kyiv, Zaporizhzhia, Lviv, Odesa, Lutsk, Melitopol;

Machine tool construction - Kharkiv, Kyiv, Berdychiv, Odesa, Cherkasy, Dnipro;

Instrument engineering - Kyiv, Kharkiv, Ivano-Frankivsk, Lviv, Sumy, Cherkasy, Zhytomyr, Lutsk;

Agricultural engineering - Kharkiv, Dnipro, Ternopil, Kherson, Odesa, Kyiv, Berdyansk, Uman, Novograd-Volynsky, Nizhyn, Kolomyia (Pihul and Pihul, 2018).

It is well-known that today resort-recreational activity is one of the most profitable businesses in the world. This sector has recently become increasingly important in the structure of national economies and is developing very rapidly; this service sector is growing much faster in the countries that give priority to the development of recreation, becoming not only an increasingly important part of national economies but also the most important State Treasury filler.

The resort-recreational sphere provides a multifaceted contribution to the formation of the country's national wealth. On the one hand, it is the income of producers of resort and recreational services, jobs creation, financial flows of wages, social transfers, taxes, rents, on the other hand investment in human capital, which is associated with social development and health of the nation. This has the effect of substituting public spending on healthcare with a more effective source of self-financing of improvement of public health through the purchase of resort and recreational services (Humeniuk, 2016).

The $21^{\text {st }}$ century opened in Ukraine with the recognition of tourism as one of the priority areas of national and regional economy. Thus, Ukraine's resortrecreational potential offers it great opportunities to become a world-class recreational State. The expansion of international relations opens new ways to promote the national recreational product on the world market, involvement in the world information space, best practices in the organization of recreation.

A significant part of the natural potential of Ukraine is: recreational landscapes (forest, coastal, mountain), health resources (mineral waters and therapeutic muds), nature reserves (national natural and regional landscape parks, biosphere reserves, park monuments of garden art, etc.), territories for historical and cultural purposes (architectural and urban monuments, historical and architectural reserves, etc.). 
These are unique resources for the long-term development of recreation areas and resorts and the best preserved part of the natural environment.

The area of developed and potential recreation areas in Ukraine (excluding radiation-contaminated) is $12.8 \%$ of the country's territory and is distributed in relation to the natural features of recreational regions: Carpathian, Transdniestria, Dnieper, Donetsk-Pryazovskyi, Polissya, Black Sea. The following factors were taken into account when determining these regions: geopolitical situation (location of the territory, availability of labor resources, transport communications, sources of raw materials, energy, history of development of the territory, traditions, etc.), availability of recreational resources, tourist infrastructure, demand for recreation and resort, tourist and recreational policy of the regions (Ivanukh and Danylyshyn, 2008).

However, socio-economic and spiritual development of society is impossible without recreation and tourism as an integral part of modern life. Ukraine, having a rich recreational and tourist potential, has all the prerequisites for the formation of a highly developed recreational and tourist economy. But the potential opportunities and resources of the resort regions of Ukraine are currently not fully used. Their further development is largely hampered by problems of legal and organizational and economic regulation.

The analysis of the tourism market shows that Ukraine has objective preconditions for intensive tourism development, but market risks, rapid changes in the economic and social situation in the regions, imperfect regulatory framework do not contribute to Ukraine becoming a tourist State of European level. Management of the tourism industry requires the search for non-traditional approaches and new views at the current stage of market transformation in Ukraine.

Unfortunately, a number of offences have been committed since the beginning of the promotion of tourism in Ukraine, along with the development of civil law relations. At the same time, inadequate legislation and lack of adaptability of law enforcement agencies in the gradual transition to a market model of legal relations have led to the spread of offenses, including those related to fraud and abuse of trust in providing tourist services to their consumers (Kaliuha, 2018).

Currently in Ukraine there are more than 1,400 hotels, tourist centers, sanatoriums and about 3,000 recreational facilities for accommodation of vacationers and tourists in Ukraine. Approximately 3 million citizens of Ukraine are employed in this sphere of economy (Savushkin, 2014).

The range of crimes committed in this area is very narrow: in particular, these are acts under Articles 149, 190, 191, 200, 212, 358, 366, 368 of the Criminal Code of Ukraine (LU 2341-III/2001, April 05). The percentage of crime structure in this area is as follows: 1) fraud (Article 190 of the Criminal Code of Ukraine) $(92.34 \%) ; 2)$ forgery of documents, seals, stamps and forms, sale or use of forged documents, seals, stamps (Article 358 of the Criminal Code of Ukraine) (3.51\%); 
Chyzh Sergịi Anatoliyovich, Shạhova Kateryna Volodymyrivna, Dereviahin Oleksii Oleksandrovich, Dal Adam Lavrentiiovych y Saltovets Sergii Anatoliyovich

3) Misappropriation, embezzlement or conversion or property by malversation (Art. 191 of the Criminal Code of Ukraine) (1.43\% ) 4) Acceptance of an offer, promise or receipt of illegal benefit by an official (Art. 368 of the Criminal Code of Ukraine (0.48\%, respectively); 5) Forgery in office (Article 366 of the Criminal Code of Ukraine) (0.96\%); 5) trafficking in human beings or other illegal agreement concerning a person (Article 149 of the Criminal Code of Ukraine) (0.96\%); 6) Illegal actions in respect of remittance documents, payment cards and other means providing access to bank accounts, and equipment for their production (Article 200 of the Criminal Code of Ukraine) (o.16\%) (Andrushko and Nesterova 2016).

The division of objects of the resort-recreational sphere can be fulfilled using such feature as participation of economic entities in the sectors of production, namely:

1) first cycle industries include consumer transportation services, hotel services and catering services.

2) recycling industries are intermediaries between service producers and consumers (travel agencies, tour operators).

3) third cycle industries are the enterprises that provide services necessary for the functioning of the first two sectors: insurance and legal companies, banks, medical institutions, sports and health and household services, etc.

4) fourth cycle industries are enterprises that provide reference and information services (Shepeliuk, 2011).

However, the results of our study have shown, not all of the above business entities commit or are involved in the commission of crimes in the economic sphere at the resort-recreational facilities.

The most significant results in the process of combating crimes in the economic sphere at the objects of the resort-recreational sphere can be achieved by organizing the operational maintenance of the following objects of the resort and recreational sphere:

1) business entities that provide hotel services.

2) travel agencies, tour operators.

3) insurance companies.

4) tour desks.

Besides, when planning activities for the formation of an agency network at resort-recreational facilities, employees of strategic investigation units of the National Police of Ukraine should take into account the location of resort and recreational facilities in the regions of Ukraine. Thus, today the 
main regions of resort and recreational complexes of Ukraine are: Odesa, Zaporizhzhia and Transcarpathian regions.

\section{Conclusions}

The activity of operational-search subdivisions is rather broad under modern conditions and is not limited to the implementation of search operations in relation to certain individuals. For the purpose of timely detection and prevention of crimes, the operational protection of individual objects is carried out, taking into account criminogenic and operational situation. The definition that characterizes such activities is known as "operational service".

Today, operational protection is carried out in order to control, monitor, analyze, assess and forecast the operational situation in the area of operational services, in industries, on the service objects, on the line of work (a type of criminal offence or a separate line of operational activity).

At the same time, the regulations of the Ministry of Internal Affairs and the National Police of Ukraine do not contain provisions that clearly define the content of the institution of operational services and its place in the system of operational and investigative units to combat crime, which, in turn affects, the practice subjective attitude to it as ordinary employees and heads of operational units.

The analysis of scientific literature on this issue showed that most scientists have studied some issues of operational protection, but mostly in the context of operational and investigative counteraction to certain crimes or relating to operational and official activities. Besides, this analysis indicates that the issues of operational protection were mostly studied by scientists within investigation of the problems and issues of operational and investigative counteraction to crimes in the area of economics. The problem of operational protection of the machine-building complex and the resortrecreational sphere by the criminal police units is almost not reflected in the works of the scientists.

That is why we identified the objects of operational protection of the machine-building complex and the resort-recreational sphere by the criminal police within this Article and drew the following conclusions:

1. The organization of operative protection of the machine-building complex by divisions of criminal police should be carried out in relation to the following objects of operative service:

a) the enterprises of heavy machine-building.

b) enterprises of agricultural (tractor) engineering. 
Chyzh Sergii Anatoliyovich, Shahova Kateryna Volodymyrivna, Dereviahin Oleksii Oleksandrovich, Dal Adam Lavrentiiovych y Saltovets Sergii Anatoliyovich

To the issue of identifying some objects of operational protection by criminal police units of the National Police of Ukraine

c) railway engineering enterprises.

d) enterprises of the automobile industry.

e) enterprises for the manufacture of electrical engineering, instrument-making, and machine tools.

2. The organization of operational protection of the resort-recreational sphere by the criminal police units should be carried in relation to the following objects:

a) business entities that provide hotel services.

b) travel agencies, tour operators.

c) insurance companies.

d) tour desks.

\section{Bibliographic References}

AMOSH, Oleksandr. 2017. In: Industry of Ukraine - 2016: state and prospects of development: scientific and analytical report. Institute of Industrial Economics, National Academy of Sciences of Ukraine. Kyiv, Ukraine.

ANDRUSHKO, Andrii; NESTEROVA, Iryna. 2016. Crime in the area of tourism: criminological characteristics and prevention: monograph. LLC "IVA". Uzhgorod, Ukraine.

ATMAZHYTOV, Valerii; ILLICHEV, Viktor. 1986. Organization of operational protection as an important direction to increase the level of investigation of crimes. Academy of the Ministry of Internal Affairs of the USSR. Moskow, Russia.

BERLACH, Anatolii. 2002. "Content and features of operational protection of financial activities of agricultural production entities" In: Scientific Bulletin of the National Academy of Internal Affairs of Ukraine. No. 2 Part 2, pp. 80-90.

HUMENIUK, Vitalii. 2016. State regulation of the resort-recreational sphere: a monograph. Kyiv National University of Trade and Economics. Kyiv, Ukraine.

ILNYTSKYI, Oleksandr. 2009. "Operational service of objects and branches of economy by the divisions of the Ministry of Internal Affairs of Ukraine" In: Viche. No. 22. Available online. In: http://veche.kiev.ua/journal/1737/. Consultation date: 21/12/2019. 
IVANUKH, Ivan; DANYLYSHYN, Bohdan. 2008. "Natural resources potential of Ukraine and the ways to improve its use" In: Economy of Ukraine. No. 1 , pp. $36-38$.

KALIUHA, Tetiana. 2018. "Forensic analysis of fraud in the area of tourist services" In: Scientific Bulletin of Dnipropetrovsk State University of Internal Affairs. No. 3. pp. 145-150.

KRAVCHENKO, Maryna; UVAROVSKYI, Ruslan. 2017. "Analysis of the effectiveness of innovative activities of domestic machine-building enterprises" In: Economic Bulletin of the National Technical University of Ukraine "Kyiv Polytechnic Institute. No. 14, pp. 405-411.

LAW OF UKRAINE. 2001. Law 2341-III/2001, April 05. Criminal Code. The Verkhovna Rada of Ukraine. Available online. In: http://zakon.rada.gov. ua/laws/show/2341-14. Consultation date: 21/12/2019.

LEKAR, Anton. 1981. To the issue of the essence of operational protection. Academy of the Ministry of Internal Affairs of the USSR. Moskow, Russia.

PIHUL, Yevhenii; PIHUL, Natalia. 2018. "Current state and prospects of development of the machine-building complex of Ukraine" In: Economy and society. No. 15, pp. 444-449.

SAVUSHKIN, Dmytro. 2014. "Development of resort and recreational systems as a tool of transformative changes in the economy" In: Efficient economy. No. 4. Available online. In: http://www.economy.nayka.com. $\mathrm{ua} / \mathrm{?} \mathrm{p}=1 \& \mathrm{z}=2919$. Consultation date: 21/12/2019.

SHEPELIUK, Serhii. 2011. "Tourist product and tourist service: criterion of differentiation the meanings" In: Economy. Management. Innovations. Vol. 1, No. 5. Available online. In: https://tourlib.net/statti_ukr/ shepeljuk.htm. Consultation date: 21/12/2019. 

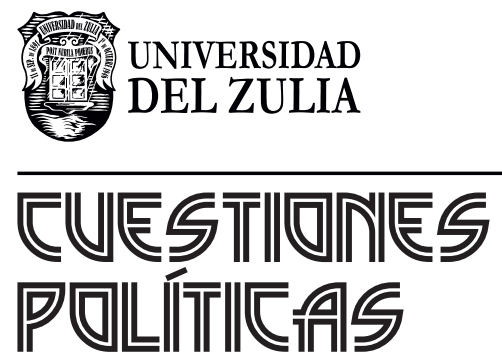

Vol.39 No 68

Esta revista fue editada en formato digital y publicada en enero de 2021, por el Fondo Editorial Serbiluz, Universidad del Zulia. Maracaibo-Venezuela 